\title{
Riverbank erosion and migration inter-linkage: with special focus on Assam, India
}

\author{
Dimpal Dekaraja* ${ }^{*}$ and Ratul Mahanta
}

\begin{abstract}
Background: Riverbank erosion becomes a vulnerable phenomenon in the bank of the Brahmaputra river and its tributaries. Around 17 riverine districts of Assam are affected by riverbank erosion and lost a large plot of land. Due to riverbank erosion the victims' loss their homestead and crop land as well as their survival strategy in the eroded areas. Moreover, farmers largely affected due to riverbank erosion as they loss their sources of income. This forces the farmer to migrate to another place for their survival. The paper examines the linkage between river bank erosion and migration based on secondary information.

Method: To examine the linkage, information collected from government published sources 'Census of India' and 'Statistical handbook of Assam'. On the basis of the information, 10 indicators constructed from 26 variables and then factor analysis method applied to examine the linkage between riverbank erosion and migration.

Results: Four variables that are agricultural worker, industrial worker, cropped area and livestock population are loaded into the first factor, for which the first factor is labeled as the socio-economic indicator. In case of second factor the two variables i.e. Migrational Growth Index (MGl) and urban population are loaded. On the basis of the loaded variables this factor labeled as demographic indicator. In case of third factor also two variables are loaded that is, Natural Growth Index (NGI) and Literacy rate. The loaded variables indicate that both $\mathrm{NGI}$ and Literacy rate are positively related. Two variables are loaded in this fourth factor i.e. river bank eroded area and the district population growth. This factor labeled as environmental indicator on the basis of the variables loaded in this factor. The factor correlation matrix indicates the opposite relation between first and fourth factor.
\end{abstract}

Conclusion: The results obtained from Factor component analysis reveals that the first and fourth factor component mainly established the linkage between riverbank erosion and migration. Besides this the component correlation matrix also reveals the inter-linkage between the variables. Thus we can say that there is positive relation between riverbank erosion and migration. However, it can be interpret that farmers mostly affected due to riverbank erosion and migrate more, because most of the inhabitants of the floodplain areas are the farmers.

Keywords: Riverbank erosion, Migration, Factor analysis, Poverty

\section{Background}

Movement of people from one location to another location caused by various factors such as economic, social, political, environmental, are termed as drivers of migration (Hoque and Hussain, 1988; Richard Black et al. 2011). But forced migration in recent decades becomes

\footnotetext{
*Correspondence: dimpolde@gmail.com

Economics Department, Nowgong College, Gauhati University, Guwahati, India
}

a common phenomenon in the world. Forced migration that caused by environmental disaster or natural disasters is termed as an environmental refugee (Bates 2002; Warren 2015). The environmental events such as degradation, soil erosion, and droughts have severe rural agricultural area to urban industrial area for getting employment (Larson et al. 2004). There are various studies that reveal the relation between environmental 
degradation and migration, such as land degradation and migration (Shah 2005; Gupta and Acharjee 2012), riverbank soil erosion and migration (Uddin and Basak 2012; Das et al. 2013) deforestation and migration (Ravindranath and Sukumar 1998), and common property resource degradation and migration (Chopra and Gulati 2001; Mahanta and Das 2012), Impact of riverbank erosion (Mollah and Ferdaush 2015), Riverbank erosion and Migration (Kamal and Abedin 2019).

Among various forms of natural disaster Riverbank erosion becomes an endemic disaster that creates long term impact (Das et al. 2014). The riverbank erosion in Yellow river of China killed 3.7 million people in 1931. The riverine country, Bangladesh is severely affected by riverbank erosion (Islam and Rashid, 2011). The major rivers of Bangladesh are Padma River, Jamuna River and Meghna River. All these rivers eroded thousands of hectares of land. But the Ganges-Padma becomes the meandering river affect the country severely (Yeasmin and Islam 2011). In Kazipur Upazilla of Bangladesh, 34.43 $\mathrm{km}^{2}$ land eroded in 2011 due to riverbank erosion and 9.35\% population of the district migrated due to this erosion (Mollah and Ferdaush 2015). Therefore, it becomes an important cause of migration from the riverine areas of Bangladesh (Kamal and Abedin 2019).

In some states of India also riverbank erosion becomes a severe natural disaster and it becomes a cause of forced migration as it creates various types of socioeconomic problem and poverty (Das et al. 2013, 2017). As per the information of National Disaster management Authority (NDMA 2014), Bihar and Assam are two highly flooded and erosion affected states in India. The riverine areas of West Bengal also severely affected to a greater extent (Chatterjee and Mistri 2013). Along the River Ganges of West Bengal, large number of riverbank inhabitant falls into the trap of poverty and migrated to nearby noneroded areas and also outside of the district (Das et al. 2017). Assam, which is mostly a plain state in northeast India, has been heavily affected by riverbank erosion since $1950 .{ }^{1}$ The state has lost 12.6 thousand hectares of land, which displaced 77.8 thousand people in 2014 (GOA 2014). There are a handful of studies which have endeavored to see the relation between riverbank erosion and population migration in Assam. Till 1985, Assam lost about $7.4 \%$ of its total area due to riverbank erosion and that leads to displacement of five thousand people (Goswami 1985). Phukan et al. (2012) estimate that since 1960-2008, the Brahmaputra River wiped out more than $4000 \mathrm{~km}^{2}$ of land and displaced more than 25 thousand villages. In the Subansiri river-basin of Assam also a huge

${ }^{1}$ Out of 33 districts in Assam, there are only two hill districts. area lost due to riverbank erosion from 1988 to 2017 (Bordoloi et al. 2020). The river bank erosion caused various socioeconomic problems and forces the riverbank inhabitants to migrate elsewhere in search of livelihood and resettlement (Mili et al. 2013; Ahmed 2016; Das et al. 2017). In this context, the objective the study formulated as to examine the linkage between riverbank erosion and population migration with an analytical approach and the factors responsible behind such migration. The hypothesis formulated as "Riverbank erosion is a cause of population migration". Thus the novelty of the study is that it tries to see the problem in an analytical way and contribute a new idea to the theory of migration. Although migration is a common problem due to riverbank erosion, few of the studies have established the linkage.

\section{Review of literature}

The theories of internal or rural-urban migration contend that migration happen due to the factors like wage differences, differences in employment opportunities as well as health and education facilities etc. (Fei and Rannis 1962; Todaro 1976). The rural people migrate when the benefits arise in the urban areas is more than the costs (Sjaastad 1962). In contrast, minimization of risk and maximization of joint income is the influencing factors of migration, according to the New Economics of Labour Migration (NELM) theory (2001). In recent decades, environmental events like flood and riverbank erosion becomes an extreme event that affects the sources of income of the victims and forces them to migrate. That is why; migration becomes a substitute measure to minimize the risk induced by environmental events (Dercon 2005; Richard Black et al. 2011).

In Bangladesh, Yamuna River affects and displaces a large number of people by eroding its bank areas and forces people to migrate somewhere else for sustaining their livelihood (Rahman 2010; Uddin and Basak 2012). The erosion severely affects the socio-economic livelihood of the riverbank inhabitants. People affected by erosion lose their agricultural land as well as properties that affect their sources of income and lead to entrapped poverty. Although erosion displaces many families, but in low eroded areas victims adopt some coping strategies like sale of land and livestock, shifting to new char land ${ }^{2}$ in Bangladesh to adjust to the erosion problem (Karim 2014). According to the study conducted by Mollah and Ferdaush (2015) more than 9\% of the population migrates

\footnotetext{
${ }^{2}$ Char are sandy tracts of land which lie in the middle of a river or adjacent to it. These tracts are created by a complex process of continuous erosion and accumulation of sand and other solid materials over a period of time To be considered a full fledged char such tracts must support vegetation and hence make settlement and agricultural activities viable.
} 
from the Kazipur Upazilla of Bangladesh owing to riverbank erosion. In Bangladesh, the loss of agricultural land and landlessness due to erosion is considered as the major contributory factor behind poverty (Rana and Nessa 2017). Adopting the origin and destination survey method in Bangladesh, Rana and Nessa (2017) finds that two-third populace of the surveyed villages migrates permanently from one union to another union by getting support from their neighbors, relatives, friends and they stayed in the destination place at lower living cost in comparison to the origin.

Another study conducted by Kamal and Abedin (2019) to see the causal relationship between riverbank erosion, migration and governance in Bangladesh. In depth interviews conducted among the migrated people who settled in the Chittagong district of Bangladesh. Using a structured questionnaire the interviews conducted to see the major problems among those erosion victims. The study finds that people migrated from various erosion affected areas and settled there. Current living conditions of those migrated people are very poor and they are trying to manage their livelihood through the rickshaw pulling and daily labor. Hence the study argued that migration may occur because of various reasons. However, migration among the riverine people because of riverbank erosion also becomes a crucial issue.

In the context of India, Das et al. (2014) conducted a study in Ganges river region under West Bengal to see the impact of riverbank erosion. The study finds that the impacts of riverbank erosion are multifarious: social, economic, health, education and sometimes political, which creates forced migration. The socio-economic impacts categorized as short term (loss of home, agricultural land, jobs and assets) and long term (direct effects on the living conditions of affected populations and indirect effects on human health and development, also referred to as the accumulation of human capital, which includes schooling of children and health status of mothers and children) impacts (Das et al. 2017). The forced migrants face different form of risk of insecurities due to erosion, such as economic insecurity due to unemployment, erosion of capital and indebtedness, social insecurity due to deprivation of civic rights, health insecurity due to lack of basic infrastructure, etc. Therefore, Das et al. (2017) suggest that there should be specific policies to protect civic rights of those migrants, and it would have been better to introduce gender specific policy (especially for female protection). Among various impacts loss of property in the form of cropland, cattle, and houses made the households more vulnerable to poverty and forces to migrate (Chatterjee and Mistri 2013).

Assam in the Northeast India largely affected by flood and riverbank erosion in the lower reaches of
Brahmaputra valley (WRD). Reviewing the population redistribution problem in Majuli sub-division of Assam, Nayak and Das (Undated) reveals that shrinkage in land area of the island over the years due to soil erosion by the mighty Brahmaputra is the main problem. ${ }^{3}$ Due to the loss of farm and homestead land, the poor people fall into poverty trap (Phukan et al. 2012). The river bank erosion destroys the existing modes of production and ways of life, breaks the family and community relations, as well as threatened the cultural identity of the people. Mili et al. (2013) in their study on Golaghat district of Assam, India, mention about various problems that arise due to flooding and erosion, such as displacement, loss of agricultural land and home, psychological effect, a poor transportation system and problems in education. Such various forms of socioeconomic problems induced by riverbank erosion compel victims to move to nearby area in search of livelihood (Baishya 2013). In another study, Ahmed (2016) finds that the impact of riverbank erosion is too severe in Barpeta district of Assam, India. Most of the affected people migrate from the eroded areas as they lose the income source. Agriculture being the main source of income, loss of crop land due to riverbank erosion they actually lose everything. In addition to that as they don't have any other coping strategy they are forced to migrate to nearby towns and cities to stabilize their income fluctuation. They mostly get employment in informal sector like pulling thela, rickshaws, unskilled construction works of buildings, roads, etc.

\section{Methodology}

\section{Study area}

Assam is the only plain state (except two hill districts) of the north-eastern region, which is geographically located between $24^{\circ} 8^{\prime} \mathrm{N}$ to $28^{\circ} 2^{\prime} \mathrm{N}$ latitude and $89^{\circ} 42^{\prime} \mathrm{E}$ to $96^{\circ} \mathrm{E}$ longitude. It consists of three valleys: Brahmaputra valley, Barak valley and North Cachar Hills with the total geographical area of $78,438 \mathrm{~km}^{2}$. Total area eroded due to erosion in Assam in 2014 was 12.58 million ha, which is $0.16 \%$ of the total area of Assam. The total population of Assam in 2011 is 31.21 million, which forms 2.58\% of the total population of India. Decadal population growth rate is $17.07 \%$ with a density of 340 persons per sq. $\mathrm{km}$. and sex ratio is 958 female against 1000 male. The economy of the state mostly depends on agricultural sector where $86 \%$ of the total population lived in rural areas. About $63 \%$ population depends on agriculture for their

\footnotetext{
${ }^{3}$ Majuli is the biggest island in the world covering $352 \mathrm{~km}^{2}$ area of land and inhabiting 1.67 lakh population (Census, 2011)

4 Brahmaputra valley is the largest valley in Assam consisting $72.29 \%$ of total land area with $50.02 \%$ of total population. The valley covers 15 districts out of 33 districts.
} 


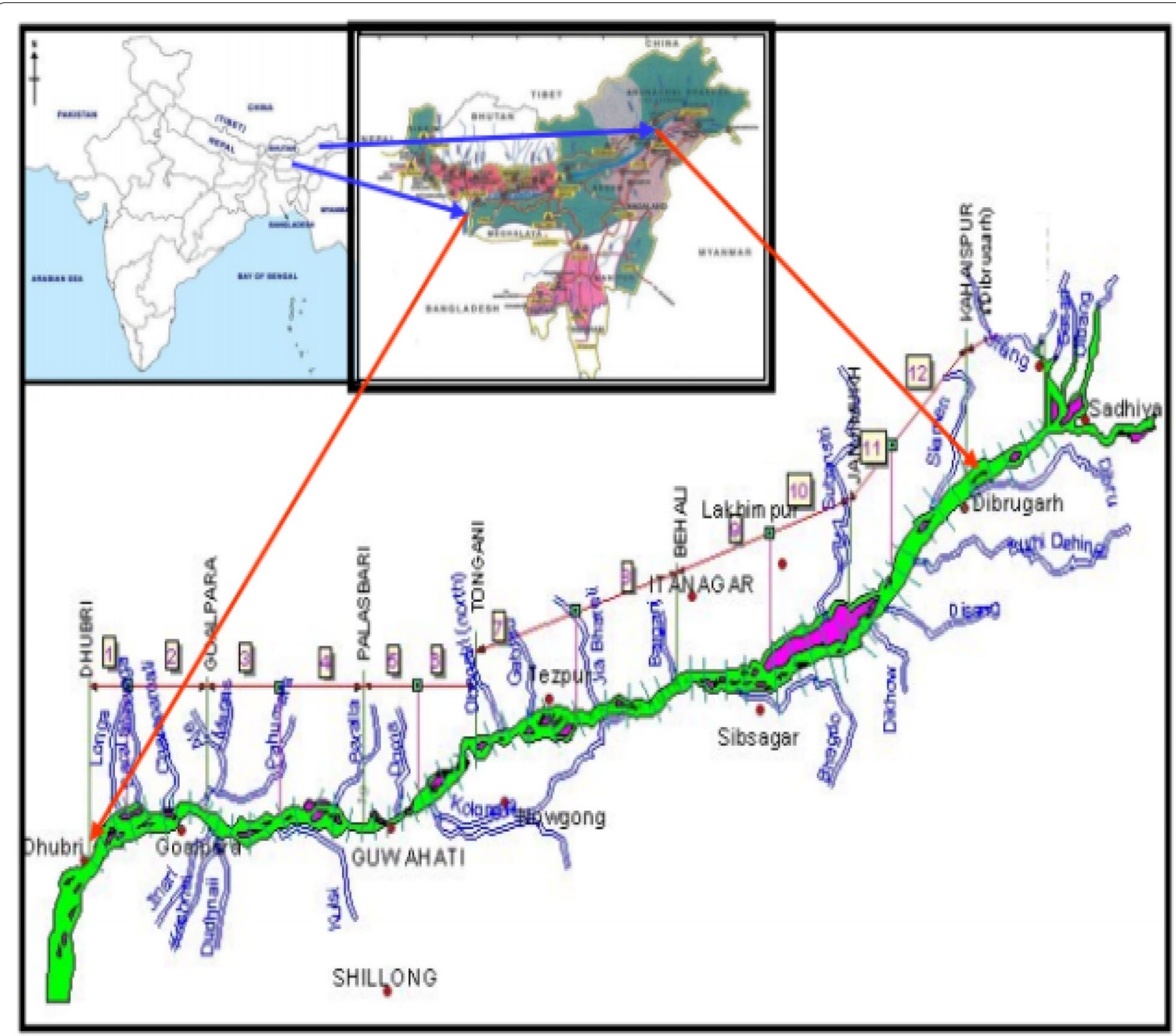

Fig. 1 Riverbank erosion Map of Brahmaputra River. 2013 Source: NDMA Commissioned IIT Roorkee Study on Brahmaputra River Erosion: A Biased and Structural Solution Oriented Report,

livelihood. Out of the total main workers in the state $36 \%$ is cultivator and $10.4 \%$ is agricultural labour. The total cropped area in Assam in 2012-13 was 4.07 million ha, which is $51.96 \%$ of the total geographical area and the average size of operational holdings is 1.10 hectares. The marginal category farmer occupied more than $67.3 \%$ of total operational holdings of land in the state. In 2011$12,31.98 \%$ of the total population is below the poverty line, out of which $33.89 \%$ are in rural and $20.49 \%$ in urban areas.

Income from livestock and poultry farming contributes a significant share in the rural economy of Assam. As per 2012 livestock census, the livestock population of the state is 19.08 million. During 2014-15, only 2629 nos. of Micro Small and Medium Entrepreneurs (MSME) units registered in the state. The small size of industries led the state and the districts into far backwardness (Fig. 1).

\section{Data source and selection of variables}

Only secondary data are used in this study. Secondary data are collected from census report of 2001 and 2011, Government of Assam, Statistical Handbook of Assam, Revenue and Disaster Management Department, Government of Assam. Information regarding villages is collected from the Circle Office of each selected 
Development Block. Primary data are collected through field survey.

To examine the linkage between riverbank erosion and migration, 26 relevant variables have been considered to represent different demographic, riverbank erosion and livestock related variables at two points of time 2005 and 2014 (see Additional file 1: Appendix). In 2004 a severe flood occurred in Assam. The information about the effect of the 2004 flood was available in 2005. Therefore, data for 2005 and latest information available till 2014 are taken for consideration. Data's related to the census are observed in two periods such as 2001 and 2011. That is why, variables related to riverbank erosion and livestock also taken in two periods. With the help of these 26 variables, 10 indicators have been constructed to represent demography related indicators, riverbank erosion indicators and livestock indicators as follows:

\section{a. Demography related indicators}

Migration is not only influenced by economic factors, it is also influenced by socio-demographic and environmental factors (Henry et al. 2003). Therefore, the estimation of migration to see environmental migration Natural Growth Index (NGI) and Migrational Growth Index (MGI) have been constructed (Chopra and Gulati 20015). To calculate NGI, Variables that are taken as Crude birth rate, percentage of married females in the age group 15-19, population density, sex ratio, literacy rate. All these variables indicate the growth of population in a specific area. Increase in the crude birth rate and increase in percentage of married females in the age group 15-19 leads to a high population growth. Lutz and Qiang (2002) argued that fertility rate and population density also influence by population growth. Thus, NGI is calculated on the basis of the factor scores of the above variables.

MGI is constructed to represent rural-urban migration. The variables that are considered for calculating MGI are rural and urban population growth, agricultural workers and industrial workers. Due to migration from rural to urban area, population in urban area increases (Bhagat 2011). Similarly, reduction in agricultural labor (increase in industrial workers) also indicates migration from agricultural to industrial areas (migration from rural to urban areas). All these variables simultaneously indicate the growth of migrated people. Taking the factor scores of all these variables MGI is calculated. The factor scores have been calculated using factor reduction method.

\footnotetext{
${ }^{5}$ MGI indicates the Migrational growth index which is prepared on the basis of some migration related variables.
}

\begin{tabular}{lll}
$\begin{array}{l}\text { Table } 1 \text { Description of variables and indicators for factor } \\
\text { analysis }\end{array}$ \\
\hline SI. No & Indicators & Description \\
\hline 1 & MGl & Migrational Growth Index \\
2 & NGl & Natural Growth Index \\
3 & U_Pop & Urban Population \\
4 & R_Pop & Rural Population \\
5 & Ind_Work & Industrial Workers \\
6 & Agr_Work & Agricultural Workers \\
7 & P_Gr & Population Growth \\
8 & R_Area & Riverbank Eroded Area \\
9 & C_Land & Crop land \\
10 & L_Pop & Livestock Population \\
\hline
\end{tabular}

\section{b. Riverbank Erosion Indicator}

Riverbank eroded area has been considered as the main variable for this indicator. However, change in cropped area is also taken as another variable as riverbank erosion leads to decrease in crop area as well as an effect on the production of food-grains (Gray and Mueller 2012; Uddin and Basak 2012). Due to bank erosion victims are compelled to migrate in search of livelihood.

\section{c. Livestock indicators}

Among livestock, population of cattle, buffaloes, and goat or sheep are taken as main variables. Loss of these livestock assets directly affect on the farmers' income and livelihood, which influence farmers' decision to migrate. These losses, mainly occur because of unavailability of fodders for the livestock population (Mahanta and Das 2012), which in turn affect livestock farming. Therefore, changes in population of cattle, buffaloes and goats are taken as important livestock indicators. Here population of cattle, buffaloes and goat are added and taken as total livestock population and then the difference of the population in the two periods of time 2005 and 2015 has been used to see the changes in livestock population (Table 1).

\section{Data analysis tools}

Factor analysis (FA) is a statistical method used to describe variability among observed correlated variables in terms of the potentially lower number of unobserved variables called factors. Hence, this method is useful to establish the link between concerned variable and the correlated variables in terms of the factors. In this study factor analysis method is used to examine the linkage between riverbank erosion and migration with the variables and indicators mentioned below. The rural-urban migration related information for the current period is not available to establish the linkage between riverbank erosion and migration. That is why, some correlated 
variables that relate to migration is taken into consideration and then applied the factor analysis technique to see the linkage. The factor analysis technique used in this study is based on the studies of Chopra and Gulati (2001) and Mahanta and Das (2012).

In our study we have observed set of ' $\mathrm{p}$ ' random variables, $\mathrm{X}_{1} \quad \ldots \ldots \ldots \ldots \ldots \mathrm{X}_{\mathrm{p}}$ (Table 1$)$, with means $\mu_{1}$ Suppose for the unknown constants $l_{i j}$ (Which indicate the factor loading) have $k$ unobserved random variables $\mathrm{F}_{\mathrm{j}}$. where, $i \in 1 \ldots \ldots \ldots \ldots . .$. , and $j \in 1 \ldots \ldots \ldots \ldots . . . k$, when $\mathrm{k}<\mathrm{p}$, then we get

$$
X_{i}-\mu_{i}=l_{i 1} F_{1}+\cdots l_{i k} F_{k}+\epsilon_{i}
$$

Here, $\epsilon_{i}$ indicates the error term which is independently distributed, with mean equal to zero and finite variances, which may not be the same for all ' $I$ '. Let $\operatorname{Var}\left(\epsilon_{i}\right)=\Psi_{i}$, so that we have

$$
\operatorname{Cov}(\epsilon)=\operatorname{Diag}\left(\psi_{i} \ldots \psi_{p}\right) \text { and } E(\epsilon)=0
$$

In matrix terms we have

$$
X-M=L F+\epsilon
$$

If we have ' $n$ ' observations, then we will have the dimensions $X_{p \times n}, L_{p \times k}$ and $F_{k x n}$. The column of $X$ and $\mathrm{F}$ indicate the values for a particular observation, but matrix $L$ never changes across the various observations.

The assumptions on $\mathrm{F}$ should be taken as.

1. F and $\epsilon$ are independent

2. $\mathrm{E}(\mathrm{F})=0$

3. $\operatorname{Cov}(\mathrm{F})=1$

The solution that will obtain from the above set of equations following the constraints for $\mathrm{F}$ is defined as the factors and $\mathrm{L}$ as the loading matrix.

\section{Results and discussion}

This section comprised of three sub-sections. At first the information related to riverbank erosion and its economic impacts are analyzed, then in the second part the results from the factor analysis are presented and discussed and in the last part results from earlier studies are presented and discussed to show a comparison with the present study.

\section{Trends of Riverbank Erosion and Impacts:}

As per the information from the report of the NDMA commission (2013), the severe erosion in the Brahmaputra river leads to loss of large plots of land during the period from 1990 to 2007-08. The length of the total erosion during the period in Assam was $742.98 \mathrm{~km}$. Out
Table 2 Year wise area Eroded and Affected population

\begin{tabular}{lllcl}
\hline Year & Area in ha & Villages affcted & Family affected & $\begin{array}{l}\text { Value } \\
\text { of property }\end{array}$ \\
\hline 2001 & 5348 & 227 & 7395 & 377.72 \\
2002 & 6803 & 625 & 17,985 & 2748.34 \\
2003 & $12,589.6$ & 424 & 18,202 & 9885.83 \\
2004 & 20,724 & 1245 & 62,258 & 8337.97 \\
2005 & 1984.27 & 274 & 10,531 & 1534.00 \\
2006 & 821.83 & 44 & 2832 & 106.93 \\
2014 & $12,579.13$ & NA & 77,805 & NA \\
\hline
\end{tabular}

Source: Water resource Department, Govt. of Assam, 2014

of which $353.85 \mathrm{~km}$ in the north bank and $389.13 \mathrm{~km}$ in the south bank of the Brahmaputra river. In terms of sq. km., total erosion during 1990 to 2007-08 was 538.80 in north bank and 914.62 in the south bank. While in the Dhubri district the total length eroded was $40.19 \mathrm{~km}$ in the north bank $\left(124.461 \mathrm{~km}^{2}\right)$ and $7.05 \mathrm{~km}$ in the south bank (194.983). As a result of this severe erosion, large number of villages and families disappear from the Brahmaputra river basin.

Since, around 17 riverine districts of Assam is affected by riverbank erosion; hence village and family affected also very high. Table- 2 presents some year wise data on area eroded and the property lost due to riverbank erosion. Data shows that a large area of land eroded in the years 2003, 2004 and 2014, for which large number of villages and families affected and displaced in 2004 and 2014. Loss of property in 2003 and 2004 was also very high. Moreover, the information from newspapers reveals that in 2016 and 2017 also heavy flood and erosion occurred that severely affected a number of districts that makes a huge loss of property to the state (Table 2).

As per government records, the number of affected families in the Palashbari and Chaygaon circles are 5521 and 871 respectively (GOA 2015). According to an unofficial report more than 2000 landless families are living in a $15 \mathrm{~km}$. stretch of the Palasbari-Nagarbera embankment in Goroimari and Palasbari Revenue Circles of Kamrup district, Assam.

As per the information obtained from the Revenue and Disaster Management Department of Assam and Water Resource Department, area eroded and losses made by this riverbank erosion are very high in 2014 (Figs. 2, 3, \& 4). Due to erosion, more than 0.07 million families affected and crores of properties lost in 2014 (Fig.4 \& 5). The two districts Dhubri and Dhemaji are highly affected by flood and erosion in 2014 (GOA 2015). Total area eroded in the Dhubri and Dhemaji districts in 2014 are 0.0016 and 0.0068 million ha. The 


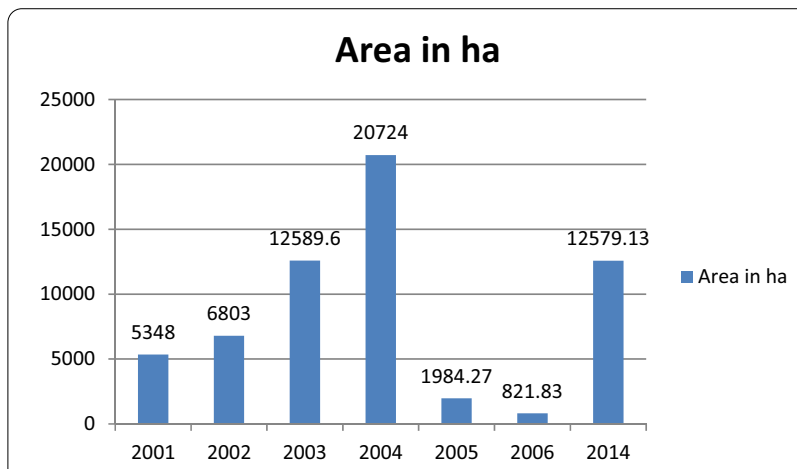

Fig. 2 Yearwise area eroded due to Riverbank erosion in Assam. Source: Water resource Department, GOA

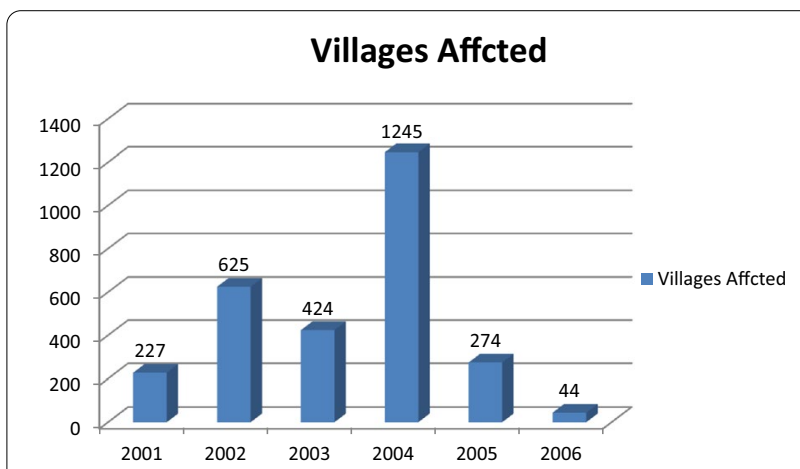

Fig. 3 Villages affected due to flodd and erosion is shown. Source: Water resource Department, GOA

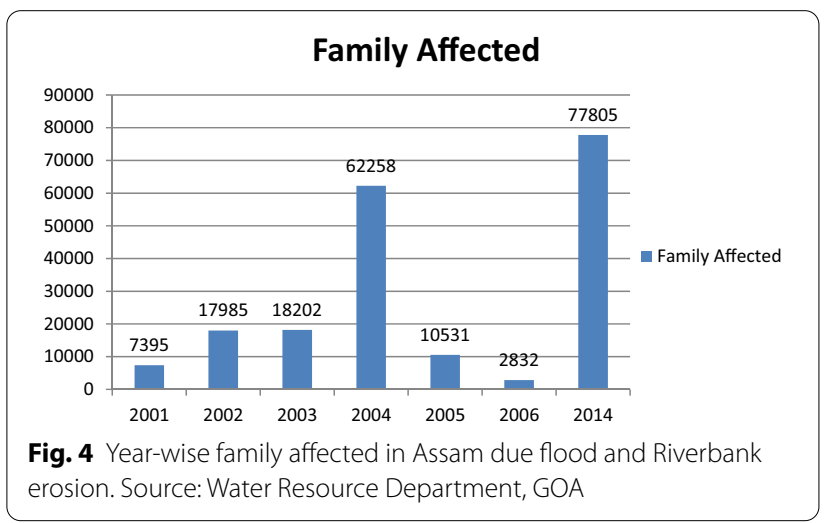

erosion displaced 0.009 million of the population in Dhubri district and 0.028 million of the population in Dhemaji district.

\section{Results from factor analysis}

The factor loading table or the rotated pattern matrix indicates four important factors based on Eigen-values

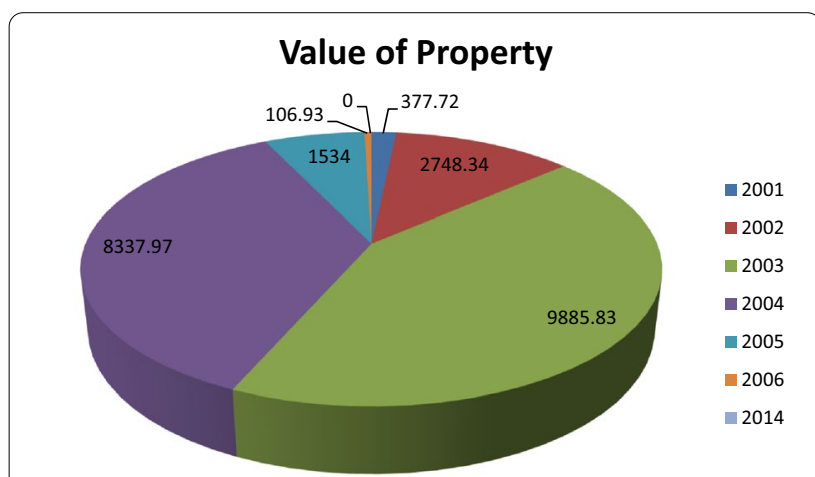

Fig. 5 Year-wise loss of property (Rs. in Crore) in Assam due to flood and erosion. Source: Water Resource Department, GOA

(Table 3). These four factors covered more than $86 \%$ variance among the variables. The factors also represent very high correlation among the observed variables. Each factor in the table represents different relations among the indicators and indicate different category of indicators.

\section{First factor}

Four variables are loaded into the first factor, such as, agricultural worker, industrial worker, cropped area and livestock population. On the basis of the variables the first factor is labeled as the socioeconomic indicator. The variables indicate a strong relationship among them. With the loaded variables, the first factor also represents its link with the second factor.

\section{Second factor}

In case of second factor the two variables i.e. MGI and urban population are loaded. On the basis of the loaded variables this factor labeled as demographic indicator. Urban population increases due to migration from rural areas as the agricultural land could not provide adequate employment opportunity in the rural areas. Behind this rural-urban migration the first factor, which represent socioeconomic indicators also have a positive effect. Various Studies and theories of migration reveals that in the rural area employment as well as other facilities related to standard of living, health and education, etc. are not available according to needs of the people (Todaro 1976; Schultz 1971; Ledent 1982). Besides, these people also face the natural disasters like drought (Shah 2005), riverbank erosion by the inhabitants of riverbank areas, floods, volcanic eruptions etc. (Uddin and Basak 2012). These all the factors often influence the decision to move to urban or any advanced location for better livelihood. 
Table 3 Obliquely rotated component loadings

\begin{tabular}{|c|c|c|c|c|c|}
\hline \multirow[t]{2}{*}{ Variables } & \multicolumn{4}{|l|}{ Factor component } & \multirow[t]{2}{*}{ Communality } \\
\hline & First socio-economic & Second demographic & $\begin{array}{l}\text { Third socio- } \\
\text { demographic }\end{array}$ & Fourth environmental & \\
\hline Agri_work & .935 & .046 & -.038 & -.057 & .893 \\
\hline Ind_work & .924 & .011 & .033 & -.137 & .869 \\
\hline Cr_area & .843 & .131 & .134 & -.112 & .798 \\
\hline Liv_pop & .843 & -.100 & .184 & .227 & .731 \\
\hline MGl & .028 & .997 & -.078 & -.002 & .996 \\
\hline$U_{-} P O P$ & -.003 & .995 & -.102 & -.028 & .993 \\
\hline$N G l$ & .290 & -.059 & .948 & .011 & .954 \\
\hline L_rate & -.161 & -.150 & .938 & .042 & .939 \\
\hline Pop_Gr & .099 & .093 & .314 & .820 & .789 \\
\hline R_Area & .184 & .119 & .356 & -.721 & .682 \\
\hline Eigen Values & 3.323 & 2.251 & 1.801 & 1.268 & \\
\hline$\%$ of Variance & 33.232 & 22.513 & 18.014 & 12.676 & \\
\hline Total Variance & & & & $86.435 \%$ & \\
\hline
\end{tabular}

Source: Calculated by Author

Extraction Method: Principal Component Analysis

Rotation Method: Oblimin with Kaiser Normalization

Variables used in this study are indicated as NGI (Natural Growth Index), MGI (Migrational Growth Index), L_Rate (Literacy rate), U_Pop (Urban Population growth), Pop_Gr (District Population Growth), Ind_Work (Industrial Workers), Agr_Work (Agricultural Worker), Cr_area (Cropped Area), R_Area (Riverbank Eroded Area), Liv_pop (Livestock Population)

\section{Third factor}

In the third factor also two variables that is, NGI (Natural Growth Index) and Literacy rate are highly loaded. The loaded variables indicate that both NGI and Literacy rate are positively related. Behind this natural growth of population the first factor or socioeconomic indicator as well as the second factor which represents the demographic indicator have strong influence. However, both the second and third factors are part of demographic indicators.

\section{Fourth factor}

Two variables are loaded in this fourth factor i.e. riverbank eroded area and the district population growth. This factor labeled as environmental indicator on the basis of the variables loaded on this factor. The negative factor loading for riverbank erosion area and positive factor loading for district population growth placed an opposite relation between the variables. This indicates increase riverbank erosion will decrease the population growth and vice versa. Besides this, the changes in population growth also influence by the previous first, second and third factor. However, the opposite relation indicates the positive effect on migration decision (Table 4).

Thus, from the above findings, it is clear that all the four factors which represent a different category are theoretically interlinked with each others, from which we can interpret the linkage between riverbank erosion and migration. In this context, the component correlation matrix indicates the correlation among those factors (Table 3). Mainly the first and second factor negatively related to the fourth factor, which indicates the opposite relation between socioeconomic factor with riverbank erosion as well as the rural urban migration and riverbank erosion. Thus the inter-linkage between the factors represents the linkage between riverbank erosion and migration. This indicates that there is a positive relation between riverbank erosion and migration.

\section{Results from earlier studies}

There are various studies conducted on riverbank erosion and its impact on socioeconomic livelihood of the inhabitants. In comparison to our study, the results of some earlier studies also reveal the truth. According to the study conducted by Mollah and Ferdaush (2015) in Kazipur Upazila at Sirajgonj District of Bangladesh

Table 4 Component correlation matrix

\begin{tabular}{|c|c|c|c|c|}
\hline Component & 1 & 2 & 3 & 4 \\
\hline 1 & 1.000 & .037 & .099 & -.031 \\
\hline 2 & .037 & 1.000 & -.048 & -.037 \\
\hline 3 & .099 & -.048 & 1.000 & .016 \\
\hline 4 & -.031 & -.037 & .016 & 1.000 \\
\hline
\end{tabular}

Extraction Method: Principal Component Analysis

Rotation Method: Oblimin with Kaiser Normalization 
reveals that riverbank erosion is the main cause of Migration; since it finds that in the year 2011, $34.43 \mathrm{~km}^{2}$ area was eroded and its percentage of total land was around $9.35 \%$ and people migrated due to this erosion is also $9.35 \%$. The total population of the Kazipur Upazila is 2, 34,804 and if the rate of erosion remains same, then in future the rate of forced migration due to riverbank erosion will be $12.75 \%$. The study conducted by Kamal and Abedin (2019) finds that as a riverine country, Bangladesh has created a complex network of river system with more than 700 rivers. Hence, riverbank erosion has become a more serious problem than flood in Bangladesh, since the victims are losing their households and agricultural land permanently every year and it creates untold suffering to the victims. Their household survey results showed that "nearly 50\% of the respondents lost their residential places and houses (40\%). More than a quarter of respondents lost their agricultural land, livestock and poultry farms (27\%) and $13 \%$ respondent lost their employment opportunities. A considerable portion (20\%) acknowledged that they lost their cultural institutions due to riverbank erosion".

Das et al (2017) in their study India, finds that various socio-economic problems arise among the flood plain inhabitants due to riverbank erosion, such as unemployment, poverty, social insecurity, displacement etc. To see the problems the study has conducted a household survey among the victims, who resettled around the nearby areas of the erosion affected areas. The study has divided the surveyed households into three groups on the basis of the distance of resettlement as Group I: Resettled within $1 \mathrm{~km}$ of the riverbank, Group II: Resettled 1-3 km from the riverbank, Group III: Resettled more than $3 \mathrm{~km}$ from the riverbank. They find that the poverty as per the Head count ratio is high in group II (i.e. 0.98), moderate in the group III (i.e. 0.81) and low in the group I (i.e. 0.78). Accordingly, the poverty gap index has also found as 0.31 in group I, 0.41 in group II and 0.33 in the group III. Thus, the head count ratio and the poverty gap reveals the severe impact of riverbank erosion on those flood plain inhabitants. Besides the above results, the study also reveals that the household condition, health and educational status also very poor. These various problems force the inhabitants/victims migrate elsewhere in search of alternative source of livelihood.

Thus, the results from various studies show that riverbank erosion is a cause behind poverty and migration. Similar the case has been observed in Assam also. The factor analysis on secondary information revealed the same fact as found in the various studies. In this context, the results from this study validated the case in Assam, India.

\section{Conclusion and recommendations}

The results from various studies and factor analysis in this study revealed that there is a close link between riverbank erosion and migration. The trends on riverbank erosion and loss property reveal that large plot of land and property lost due to riverbank erosion in Assam. Besides this a large number families also displaced as a result of riverbank erosion. Thus, it is clear that what will do by the displaced people? They will of course migrate to another place in search of livelihood and resettlement. Factor analysis results in this study show this linkage between river bank erosion and migration. The first and fourth factors mainly indicate the linkage between the two concepts. Further the component correlation matrix reveals that rural-urban migration is related to the environmental degradation i.e. Riverbank erosion. Besides this, results from various studies shows that riverbank erosion creates different forms of socioeconomic and demographic problems such as loss of livelihood, loss of education and falling health condition, loss of homestead land etc. that ultimately forces the victims to migrate. These all forms of socioeconomic problems compel the victims to migrate elsewhere.

Although the above analysis revealed that there is a close linkage between riverbank erosion and human migration; it doesn't want to claim that the nature is the main reason behind the population migration. There are various causes as contended in the migration theories, among which nature (Riverbank erosion) may be a cause. However, further in-depth study needed to see the problem in depth that is what are the various impacts of riverbank erosion? What are the coping measures adopted by the erosion displaces? The extent of population migration due to riverbank erosion and Type of migration, whether it is short term or long term?

\section{Supplementary Information}

The online version contains supplementary material available at https://doi. org/10.1186/s40068-020-00214-0.

Additional file 1. Appendixes.

\section{Acknowledgements}

At first I am very grateful to my research supervisor, he suggest me and guide me to write a research paper. I am also thankful to those offices personal, who helped me to collect information from government source, i.e. Census of India and Statistical Handbook of Assam.

\section{Authors' contribution}

The first author has the major contribution in this research. All the data analysis and discussion of results has been made by the first author. The second author mainly helped in reviewing the analysis and discussion and also helped in preparing the paper in a required format. Both authors read and approved the final manuscript. 


\section{Funding}

There is no any funding source. Actually the paper is a part of my research work and written on self interest and self funding.

\section{Availability of data and materials}

The data used in this study are from published sources of government of India; hence it may be available in another study also. But, the analysis is different from other research works. Since the method of analysis is different from other.

\section{Ethics approval and consent to participate}

We the author(s) of the manuscript entitled "Riverbank Erosion and Migration Inter-Linkage: with special focus on Assam, India", hereby declare that the paper is our original work and results of this paper did not published or waiting for publication in any other source. The data and information used in this paper are collected by us from various government sources like, Census of India, Statistical handbook of Assam, India, and from the Circle office of each development block.

\section{Consent for publication}

We also like to assure that there is no any conflicting issue in our research work, since it is a part of doctoral research done by the first author at the University of Gauhati, Assam, India. So, we would like to contribute our research work for review and publication in your journal.

\section{Competing interests}

However, we would like to inform that the method of analysis mainly borrowed from two research work, one done by Chopra and Gulati on "Land degration and migration" and the other done by Ratul Mahanta and Daisy Das on "Common Property resource degradation and Migration". Hence, there may be some similarity in the method. But, the data and analysis are completely different.

Received: 2 August 2020 Accepted: 14 December 2020

Published online: 18 January 2021

\section{References}

Ahmed SF (2016) Impact of Disasters Caused by Riverbank Erosion by Brahmaputra under Barpeta District, Assam-A Case Study. Imperial J Interdisciplinary Research 2(8):1213-1217

Bates DC (2002) Environmental refugees? Classifying human migrations caused by environmental change. Popul Environ 23(5):465-477

Bhagat RB (2011) Emerging pattern of urbanisation in India. Econ Political Wkly 46(34): 10-12. http://www.jstor.org/stable/23017782

Baishya SJ (2013) A Study on River Bank Erosion by the river Baraliain Melkipara Village of Hajo Revenue Circle, Kamrup District, Assam, India. Int J Scientific Res Publications 3(9):1-10

Chatterjee S, Mistri B (2013) Impact of river bank erosion on human life: a case study in Shantipur Block, Nadia District, West Bengal. Int J Human SocSci Invent 2(8):108-111

Chopra K, Gulati SC (2001) Migration, common property resources and environmental degradation: inter linkages in India's Semi-Arid regions. Sage Publication, New Delhi

Das TK, Halder HK, Gupta ID (2013) Forced migration: consequences of river bank erosion in India. SSRN Electr J. https://doi.org/10.2139/ssrn.2366374

Das KT, Halder HK, Gupta ID (2014) River bank erosion induced human displacement and its consequences. Living Rev Landsc Res. https://doi. org/10.12942/lr|r-2014-3

Das TK, Halder HK, Gupta ID (2017) Impact of riverbank erosion: a case study. Australas J Disaster Trauma Stud 21(2):73

Dercon S (2005) Insurance against poverty. Oxford University Press, Oxford

Fakhruddin SHM, Rahman J (2015) Coping with coastal risk and vulnerabilities in Bangladesh. Int J Disaster Risk Reduction 12:112-118

GOA (2014) Information on Riverbank erosion and Population Displacement. Revenue and Disaster Management Department, Government of Assam

GOA (2015) Statistical Handbook of Assam 2015. Government of Assam, Government Press, Directorate of Economics and Statistics

Goswami D (1985) Brahmaputra River Assam, India: Physiography, Basin denudation and channel aggradation. Water Resour Res 21(7):959-978
Gray CL (2009) Environment, land, and rural out-migration in the Southern Ecuadorian Andes. World Dev 37(2):457-468

Gray CL, Mueller V (2012) Natural disasters and population mobility in Bangladesh. ProcNatlAcadSci 109(16):6000-6005

Haque CE, Hussain Z (1988) River Bank Erosion in Bangladesh. Am GeogrSoc 78(1):20-31

Henry S, Boyle P, Lambin EF (2003) Modelling inter-provincial migration in Burkina Faso, West Africa: the role of socio-demographic and environmental factors. Applied Geography 23(2-3):115-136

Islam F, Rashid ANM (2011) Riverbank erosion displacees in Bangladesh: need for Institutional Response and Policy Intervention. Bangladesh J Bioeth 2(2):4-19

Kamal M, Abedin MJ (2019) Riverbank erosion and migration: a study on displaced people from governance and cultural perspective. Soc Change XII I(4):202-227

Karim AHMZ (2014) Flood and riverbank erosion displacees: their indigenous survival strategies in two coastal villages in Bangladesh. Can Cent SciEdu. https://doi.org/10.5539/ass.v10n4p16

Kotoky P et al (2005) Nature of Bank Erosion along the Brahmaputra River Channel, Assam, India. CurrSci 88(4):634-639

Larson DF, Anderson JR, Varangis P (2004) Policies on Managing Risk in Agricultural Markets, The World Bank Research Observer, vol 19. Oxford University Press, pp 199-230. Available at: http://www.jstor.org/stable/3986558

Mahanta R, Das D (2012) Common property resource degradation and migration: a Study of Assam. J Human Ecol 38(3):223-230

Mili N, Acharjee S, Konwar M (2013) Impact of flood and river bank erosion on socio-economy: a case study of Golaghat Revenue Circle of Golaghat District, Assam. Int J Geol Earth Environ Sci 3(3):180-185

Mollah TH, Ferdaush J (2015) Riverbank erosion, population migration and rural vulnerability in Bangladesh (a case study on KazipurUpazila at Sirajgonj District). Environ Ecol Res 3(5):125-131

Nayak DK, Das D (Undated) An assessment of redistribution of population in Majuli Island due to river bank erosion.

NDMA (2013) Vulnerability profile of India. http://www.ndma.gov.in/en/vulne rability-profile.html

NDMA (2014) Information on floods. http://www.ndma.gov.in/en/media-publi c-awareness/disaster/naturaldisaster/

NELM (2001) Remittances and Development in Mexico: The New Labour Economics of Migration: a Critical Review. Taylor and Fletcher, Rural Mexico Research Project, p 2

Phukan A, Goswami R, Borah D, Nath A, Mahanta C (2012) River bank erosion and restoration in the Brahmaputra River in India. Clar Multidiscip Int J 1(1):1-7

Rahman MR (2010) Impact of river bank erosion hazards in the Jamuna floodplain areas in Bangladesh. J Sci Found 8(1 \& 2):55-65

Ravindranath N, Sukumar Raman (1998) Climate Change and Tropical Forests in India. Climatic Change. 39:563-581. https://doi.org/10.1023/A:10053 94505216

Rana MS, Nessa AM (2017) Impact of riverbank erosion on population migration and resettlement of Bangladesh. Sci J Appl Math Stat 5(2):60-69

Richard Black W, Adger N, Arnell NW, Dercon S, Geddes A, Thomas D (2011) The effect of environmental change on human migration. Global Environmental Change 21:S3-S11

Sarma JN, Acharjee S (2012) A GIS Based Study on Bank Erosion by the River Brahmaputra around Kaziranga National Park, Assam, India. Earth SystDyn Discuss 3:1085-1106

Shah A (2005) Land degradation and migration in dry land region in India, Sandee 10(5)

Sjaastad LA (1962) The Costs and returns of human migration. J Polit Econ 70:80-93

Todaro MP (1976) Internal migration in developing countries: A review of theory, evidence, methodology and research priorities. American Economic Association 59(1):138-148

Uddin AFMA, Basak JK (2012) Effects of riverbank erosion on livelihood. Dhaka, UnnayanOnneshan, Centre for Research and Action on Development

Yeasmin A, Islam MN (2011) Changing trends of channel pattern of the Ganges-Padma river. Int J GeomatGeosci 2(2):669-675

Warner K (2010) Global environmental change and migration: Governance challenges. Global Environmental Change 20(3):402-413

\section{Publisher's Note}

Springer Nature remains neutral with regard to jurisdictional claims in published maps and institutional affiliations. 